\title{
Exploration of English Teaching in Higher Vocational Colleges from the Perspective of Culture
}

\author{
Qing Li \\ Sichuan Vocational College of Information Technology, Sichuan 628040, China \\ 545196367@qq.com
}

Keywords: Higher vocational colleges; English teaching; education culture.

\begin{abstract}
In order to really reflect the current situation of English teaching in higher vocational colleges, and to clarify, analyze, and solve the problems of higher vocational English culture teaching, we select three vocational colleges for empirical research, to make an in-depth analysis of the existing problems in English culture teaching in higher vocational education. What's more, on this basis, we put forward the strategies and suggestions. The research results show that through the design and analysis of the case of composition culture teaching, it provides practical reference for English culture teaching in higher vocational colleges. And it is concluded that teachers, as the leader of cultural teaching, should not only improve the students' basic language skills, but also pay attention to the cultivation of students' acquisition of cultural thinking, humanistic quality and comprehensive quality, so as to provide the way to sense the world, to enhance their humanistic quality and to promote the comprehensive development.
\end{abstract}

\section{Introduction}

For a long time, public English, as one of the general courses in higher vocational colleges, has not been paid enough attention to. Higher vocational education is a professional education mode, which is to train applied talents. While the school is more concerned about the students' future employment and ability to adapt to society, so a lot of financial resources are put into the relevant professional equipment update and students' skills training [1]. But we need to be clear that, with the increase of international exchanges and cooperation under the background of economic globalization, English as the language for communication between the political, economic and cultural exchanges, is increasingly important. Higher vocational colleges, in personnel training, should not only focus on professional skills, but also pay attention to improving the students' English level.

In the past, the training target of non-English majors' students was the level of listening, speaking, reading and writing skills, while ignoring the cultivation of students' cultural awareness, cultural understanding and intercultural communicative competence. In today's international communication, only skills are far from enough. Because of the difference of social background, political system, ideology, way of thinking, and concept psychology and other aspects of Chinese and foreign people, they will have different understanding of the same thing. If we do not understand each other's culture and customs, the effective communication will not be sustained, and it will greatly affect the future foreign language communicative ability of students and influence the economic cooperation. Therefore, we should attach importance to culture teaching in higher vocational English teaching.

We take three different kinds of Higher Vocational Colleges in Guiyang City as the objects, namely Guizhou Industrial and Commercial Career Academy, Guizhou Construction Career Technical College, and Guizhou Infant Normal University, Academy College. The application status of culture teaching in English teaching is investigated, so as to clarify the understanding of teachers and students in Higher Vocational Colleges of English culture teaching, and to understand the existing problems of English culture teaching in Higher Vocational Colleges. What's more, we analyze its causes, and accordingly we give advice. As a result, it suggests that the study of cultural teaching in Higher Vocational English teaching has the enlightenment and reference significance in the current English education reform. 


\section{Investigation and analysis on the current situation of English teaching in higher vocational colleges}

\subsection{Investigation design}

Investigation target: English teaching should not only cultivate the basic skills of language, but also put this kind of learning and training into the background of cultural teaching, so as to finally enable students to acquire social communicative ability. The purpose of this investigation is to understand the status of implementation of culture teaching in English teaching in Higher Vocational Colleges in Guizhou Province, to understand the importance of culture teaching and English teachers in specific teaching implementation, and to understand students' intercultural awareness and intercultural communication level status [2].

Investigation objects: The survey was conducted by 600 students and 25 English teachers from Guizhou Industrial and Commercial Career Academy, Guizhou Construction Career Technical College, and Guizhou Infant Normal University, Academy College. The selection of samples is very important, and the representativeness and universality should be reflected.

Investigation method: In 1977, Follett, a language testing scholar, put forward a cultural testing model, which mainly tests students' cultural awareness, social etiquette, understanding of cultural differences and cultural values and so on. It is a mature and far-reaching test volume.

A total of 600 students questionnaires were issued, and 592 valid questionnaires were collected, with a recovery rate of $98.7 \%$. A total of 25 teachers questionnaires were issued, and 25 valid questionnaires were collected, with a recovery rate of $100 \%$ [3]. we use the statistical software Excel form to analyze the test paper, mainly for statistic of the accuracy of answers, and for correlation analysis according to the percentage data. What needs to be illustrated is that, intercultural communication test answers are fixed, so in the table, the right option is indicated by bold black way [4]. The investigation of teaching English culture volume answer is open, and the solution is not unique, not marked in the table, only displaying the statistical results.

\subsection{Results analysis}

Data statistics and analysis of students' test volume are shown as follows:

Table 1. A survey of students' attitudes towards English culture learning

\begin{tabular}{|c|c|c|c|}
\hline & A & B & C \\
\hline Question 1 & $362(61.15 \%)$ & $119(20.10 \%)$ & $11(1.85 \%)$ \\
\hline Question 3 & $227(38.35 \%)$ & $256(43.24 \%)$ & $109(18.41 \%)$ \\
\hline Question 4 & $214(36.15 \%)$ & $315(53.21 \%)$ & $63(10.64 \%)$ \\
\hline Question 10 & $482(81.42 \%)$ & $106(17.91 \%)$ & $4(0.67 \%)$ \\
\hline Question 13 & $87(14.70 \%)$ & $219(36.99 \%)$ & $286(48.31 \%)$ \\
\hline
\end{tabular}

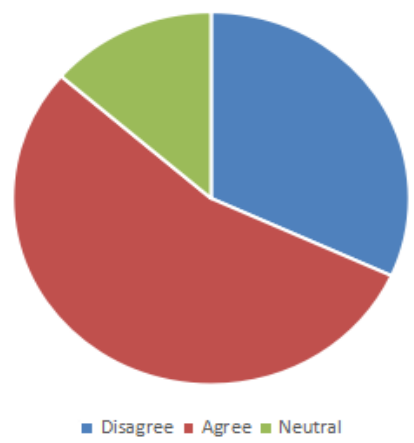

Figure 1. The results of question 4 


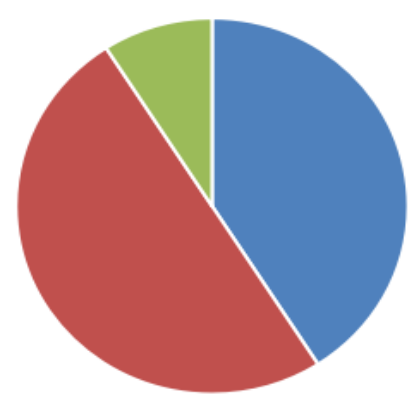

- Try to accept $\mid$ Resist $\mid$ - Fully accepted

Figure 2. The results of question 13

Based on the above findings, it can be concluded that $61.15 \%$ of the students believe that it is very important to understand the cultural knowledge of English speaking countries in English learning, which shows that students have realized the importance of cultural learning to English learning. At the same time, the cultural knowledge of English speaking countries plays an important role in improving students' interest in learning English. According to the survey results of question 10, more than $80 \%$ of the students think that English cultural knowledge is quite essential in improving their English learning interest. But next, in question 3, "Is it helpful to understand English culture for the improvement of English proficiency?" [5], 256 students thought it was normal, and 109 students said that it has little help, accounting for $61.65 \%$ of the total number. Questions 4 and 13 are relatively relevant subjects to examine students' attitudes towards foreign cultures. For the "foreign cultural threat", there are $63.85 \%$ students holding agreed or neutral attitude. When faced with cultural conflicts, for some behavior performance incompatible with the traditional Chinese custom, 36.99\% of the students response to accept, and $48.31 \%$ students have psychological conflict, emerging the "cultural inertia" [6]. That is to say, students still show a strong attachment to their own culture, and have different degrees of rejection of foreign culture, resulting in psychological rejection.

Table 2. Feedback survey of teachers' classroom teaching

\begin{tabular}{|c|c|c|c|}
\hline & A & B & C \\
\hline Question 5 & $325(54.90 \%)$ & $203(34.29 \%)$ & $64(12.81 \%)$ \\
\hline Question 7 & $140(23.65 \%)$ & $417(70.44 \%)$ & $35(5.91 \%)$ \\
\hline Question 9 & $338(57.09 \%)$ & $59(9.97 \%)$ & $195(32.94 \%)$ \\
\hline Question 12 & $207(34.97 \%)$ & $101(17.06 \%)$ & $284(47.97 \%)$ \\
\hline Question 15 & $72(12.16 \%)$ & $264(44.59 \%)$ & $256(43.25 \%)$ \\
\hline
\end{tabular}

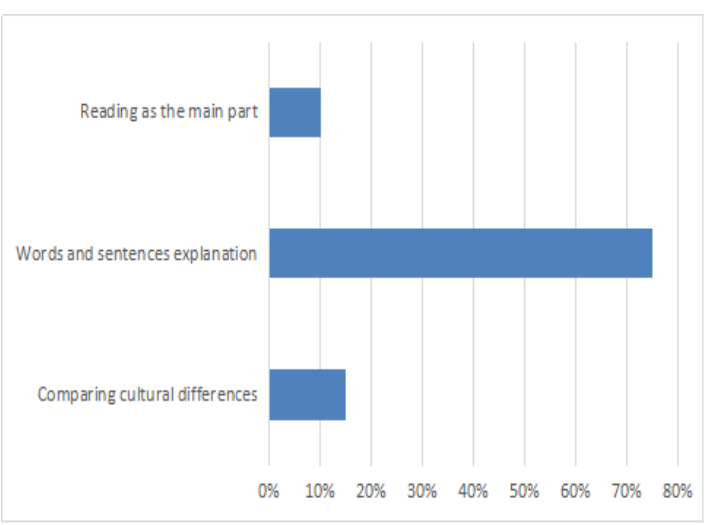

Figure 3. The results of question 7

The above five questions mainly test the student feedback on the effect of classroom teaching. In question 5, the English classroom atmosphere showed that $54.90 \%$ of students think that the classroom atmosphere is boring, the teacher is still in the traditional echo of what the books say and teachers do not create a good and positive classroom atmosphere in the teaching process, which will not stimulate students' learning enthusiasm and initiative. In dealing with part of the contents of culture textbooks, teachers focus more on words and sentences explanation on the basis of reading comprehension 
(70.44\%), and not paying further attention to cultural content [7]. Only part of the teachers let students to read related cultural knowledge after class $(23.65 \%)$ or choose to use multimedia material to let the students understand the related content $(47.97 \%)$, which cannot reach the culture teaching effect. Teachers pay too much attention to language knowledge, and such teaching method will inevitably result in that students' English learning enthusiasm is not high, and the class participation degree is low, thereby affecting the improvement of their English comprehensive ability [8].

\section{Some suggestions on the implementation of cultural teaching from the perspective of culture}

\subsection{English education and cultural teaching: changing the traditional concept of English education and attaching importance to cultural teaching}

The essence of education is the cultural transmission based on love. It is not simply a cultural transmission, not a mere transfer of cultural knowledge, but the guidance of traditional force of human beings and the awakening of personality and soul. Therefore, the purpose of English education is not language or cultural knowledge simple transfer, but on the basis of language and culture learning, with cultural communicative ability as the center, to create the perfect personality, cultivate students' respect for cultural diversity and difference as well as tolerant attitude. It also aims at forming a good world outlook and values so as to meet the requirements of the times. This requires teachers to change the traditional teaching method focusing on the language [9]. It is necessary to start from language learning, language awareness, cultural awareness and intercultural communication ability, to strengthen students' culture learning experience, improve students' choice ability, critical ability and reflection ability in the face of different culture, and enhance students' cultural literacy.

At the same time, teachers should study the theory of education and teaching, innovate the teaching mode and change the teaching mode of translation - grammar [10]. Nowadays, English experience teaching, constructivism teaching, and task-based teaching, as the new teaching theory and the teaching mode, have been paid much attention to. Teachers should carry out in-depth study, carefully study and integrate culture teaching into the above teaching mode. In addition, it is necessary to construct and create new teaching mode by combining with their own teaching practice and students knowledge and experience. For example, taking experience English teaching as an example, teachers should make full use of multimedia and cyber source, create a real language and cultural environment, attach importance to the analysis of the culture contained in the language, and gradually transform students' Chinese way of thinking. In this way, students can sense the diversification of culture in English context, and cultivate the respect attitude towards foreign culture. In a word, teachers should change the concept of English education, attach importance to cultural teaching, and pay attention to ideological and behavioral changes.

\subsection{English education and language teaching: emphasizing on grammar, vocabulary, text and other language levels of cultural exploration}

The process of mastering language competence is the process of individual individualization and individual socialization development. The process of English education is a process of learning the English language. And it is the process of development of students in language learning process. It is also the process to improve the language communication skills on the basis of mastering English vocabulary, grammar and sentence structure and so on. Therefore, we should not neglect the cultural exploration in all levels of language teaching [11]. For example, in vocabulary teaching, vocabulary is regarded as a summary of the thoughts, interests, habits and so on contained in the national language, and it has a rich cultural connotation. Consequently, it is far from enough only to lead the students to read the words in the teaching or understand the meaning. Teachers should pay attention to the words and the meaning, take it as an important part of cross cultural teaching in the foreign language teaching, and make an analysis of the utilization scope of vocabulary and cultural connotation [12]. In grammar teaching, teachers can find the cultural roots of different languages by differentiating the tense in 
different languages and comparing the similarities and differences between word order and sentence structure, such as thinking differences, and combining grammar teaching with culture teaching.

\subsection{Cultural communication and English education: changing the role of teachers and improving the ability of cultural teaching research}

Education is a social activity that spreads culture with purpose. Teachers play a leading role in educational activities, and the main communicator of cultural information is teachers. The process of cultural communication generally starts with teachers, and finally, goes through interaction between teachers and ends with students. Therefore, the role of teachers is particularly important. English education is the process of English cultural communication, which is based on China's local culture integrating with western culture [13]. It aims at creating new culture and promoting the students' cultural competence development. As a result, how English teachers position themselves and the education value orientation of them are essential for improving the quality of English teaching. In the new era, teachers should change their roles in the past, become the culture critic analysis and the founder of new culture, and improve the ability of cultural teaching research. Teachers are also supposed to cultivate cultural sensitivity, to notice the differences between curriculum resources inside and outside culture and Western culture, and to objectively analyze the pros and cons of the cultural differences. Therefore, they can extract cultural traits produced by culture collide of two kinds of culture, but not simple attachment of two culture [14]. In this way, teachers can help students to better achieve cross-cultural communication and understanding. More importantly, teachers should improve the ability of cultural teaching research, including the expansion of cultural knowledge, the organization ability of teaching material content, the development of English curriculum resources and so on.

\section{Conclusion}

In higher vocational colleges is an important part of modern occupation education, which has its special status and significance of social development. It is mainly reflected in the employment as the main goal, and being engaged in an occupation or labor needed knowledge and skills as the main teaching content. Thus, it determines the speciality of its object and target - to cultivate skilled talents. What we need is a modern man with international vision and spirit of the times. The significance of English courses in higher vocational colleges is not only to enable students to acquire basic language skills, but also to enhance intercultural communication awareness and the ability to understand Chinese and Western cultures in the cultural exchanges between China and the west. This kind of ability is spiritual, and in the future, it affects people's subjective value in a potential and implicit way. Therefore, we call for that higher vocational colleges should attach importance to English culture teaching. The classroom is the place for English culture teaching, and teachers are the leader of cultural teaching, whose responsibility is more important. Teachers should not only improve the students' basic language skills, but also pay attention to the cultivation of students' acquisition of cultural thinking, humanistic quality and comprehensive quality. As a result, it provides ways for the students to understand the world, to promote their own humanistic quality and to promote the overall development.

\section{References}

[1] Kuteeva, M., \& Airey, J. (2014). Disciplinary differences in the use of English in higher education: Reflections on recent language policy developments. Higher Education, 67(5), 533-549.

[2] Kanno, Y., \& Kangas, S. E. (2014). "I'm Not Going to Be, Like, for the AP” English Language Learners' Limited Access to Advanced College-Preparatory Courses in High School. American Educational Research Journal, 51(5), 848-878.

[3] Appleby, R. (2013). Singleness, marriage, and the construction of heterosexual masculinities: Australian men teaching English in Japan. Portal: Journal of Multidisciplinary International Studies, 10(1), 1 . 
[4] Swanson, E., Wanzek, J., McCulley, L., Stillman-Spisak, S., Vaughn, S., Simmons, D., ... \& Hairrell, A. (2016). Literacy and text reading in middle and high school social studies and English language arts classrooms. Reading \& Writing Quarterly, 32(3), 199-222.

[5] Gregory, A., \& Huang, F. (2013). It Takes a Village: The Effects of 10th Grade College - Going Expectations of Students, Parents, and Teachers Four Years Later. American journal of community psychology, 52(1-2), 41-55.

[6] Lee, J. S., Blackwell, S., Drake, J., \& Moran, K. A. (2014). Taking a leap of faith: Redefining teaching and learning in higher education through project-based learning. Interdisciplinary Journal of Problem-Based Learning, 8(2), 2.

[7] Marcellino, M. (2015). English language teaching in Indonesia: A continuous challenge in education and cultural diversity. TEFLIN Journal, 19(1), 57-69.

[8] Alrashidi, O., \& Phan, H. (2015). Education context and English teaching and learning in the Kingdom of Saudi Arabia: An overview. English Language Teaching, 8(5), 33.

[9] Hodge, E., \& Benko, S. L. (2014). A" common" vision of instruction? An analysis of English/Language Arts professional development materials related to the Common Core State Standards. English Teaching, 13(1), 169.

[10] Kubota, R. (2015). Questioning language myths in English language teaching: Toward border -crossing communication. In Selected papers from the twenty-fourth international symposium on English teaching (pp. 44-57).

[11] Wang, L. Y., \& Lin, T. B. (2013). The representation of professionalism in native Englishspeaking teachers recruitment policies: A comparative study of Hong Kong, Japan, Korea and Taiwan. English Teaching, 12(3), 5.

[12] Shouren, W. A. N. G. (2015). Individualized English language teaching in the context of contemporary China: Notions and practices. Foreign Languages and Their Teaching, 4, 001.

[13] McCahon, R. A., \& Whynes, D. K. (2015). Cost comparison of re - usable and single - use fibrescopes in a large English teaching hospital. Anaesthesia, 70(6), 699-706.

[14] Zhu, W., Deng, X., \& Li, J. (2014). A Case Study on Teaching Business Courses in English or Bilingualism with Guangwai as an Example. English Language Teaching, 7(9), 156. 